\title{
Social Justice a Crucial Factor in the Social Equality
}

\author{
Xhabir Zejnuni \\ Ph.D. candidate at the UET University
}

Doi:10.5901/mjss.2014.v5n27p1275

\begin{abstract}
Nowadays everywhere we talk about justice and social equality and this fact imposes on us first of all to have clear ideas about security, welfare, politics, differences, multiculturalism, knowledge and virtues of anyone. Social justice is one of the most important factors that legitimize social, economic and political orders. It is very important to prove the link between social justice and human dignity, which is expressed entirely under the concept of social equality. However, the issue of social justice is closely linked to the phenomenon of inequality created by unequal distributions of various resources between individuals and between different social groups. The use of term "social justice" dates back to the mid-nineteenth century, which coincides with the intensification of the processes of industrialization and democratization. Social equality is a contemporary legal-political key concept and express values, ideas, normative principles, objectives and criteria of justice. The major issue about social equality is that it is greatly proclaimed and expressed in constitutional cards, but on the other hand it actualizes with difficulties in everyday life. For this reason, many questions arise, such as: what does usually express the term equality; do the natural diversities between people constitute restrictions, or are resources in the interest of community; how social diversity should be managed to protect the dignity of every human being? Justice must coincide with the legality, or as argued by many with the equality. Social justice is the basis of social equality. Consequently, there can be no social equality if there is no preliminary social justice. Social justice influences social equality between the sexes, between different ethnic groups, between different age groups, between individuals with different cultural backgrounds, etc. Equality can be of various types: economic, political (horizontal and vertical), formal or substantive, options, etc.
\end{abstract}

Keywords: social justice, social equality, cultural differences, politics and economics.

\section{Social Equity}

Nowadays it is of a great importance the social justice, which is a prerequisite for social equality, since if there is no social justice, then there cannot be social equality. Equality is a situation in which any individual or community should be considered equal, but especially in the civil, political, social and economic rights. For this reason, democratic constitutions provide the equality of citizens through free participation in political life in order to guarantee equal opportunities in society, giving all individuals the same opportunities for personal and professional achievements. For social equality are very important the means of distribution of goods ${ }^{1}$ between individuals and groups, as to distribute even, brings acceptance as exact equality in the distribution of these goods. Equality must put as the main aim the reduction of inequalities of different sources, and should never interfere in the personality of the subjects. Should be favored a democracy that must take into account a part of society, which is located in a disadvantaged position, providing the means to break the deadlock. Should be given special attention the skills of individuals to develop their potential and skills in a society that actually allows them to use later. There is no question that welfare should be distributed between persons equally, but that threshold is reached, which means that everyone should have an equal chance at the beginning. Even Pope Benedict XVI has said that "humanity's last option is always among those who believe that every life realizes a truth, and those who think that treating the essential issues is only strength"2.

About the equality is spoken of in many ways, including the formal and political way.

The first is that all members of society are absolutely equal in rights and duties regardless of their sex, origin, race, wealth, religious or political conviction, and should not be discriminated. The ideals of equality have found inspiration in the declaration of the rights from England of the Magna Carta Libertatum of 1215 and especially in the USA with American Declaration of Independence in 1776 and France's Declaration of the Rights of Man and Citizen adopted by the French Constitutional Assembly in 1789, through which is build the foundation of a new political order.

The principle of equality can be seen on several levels:

\footnotetext{
1 The Goods are referred to both goods and services.

2 Pop Benedict XVI. Discussion held before German Bundestag in 2007.
} 
- Civilian level, which relates to equality under the law and the rights and freedoms, as judicial guarantees, freedom of conscience, etc.;

- Political level, which relates to equal participation in power through the right to vote;

- Social level, which relates to equality in the possession of economic resources.

The scope of equality socially and politically is linked with social relationships of individuals or groups with each other, or with a group of individuals and vice versa.

There are different forms of equality about people and social situations, such as equality between the sexes in terms of access to employment, or equality of equal opportunities that conveys the idea that people should be exposed to the same conditions of starting in life, or that everyone should have equal opportunities regardless of their birth and heritage. In this regard, the peak is marked by the removal of privileges from the American Revolution of 1791 and the Declaration of the Rights of Man and of the Citizen in France in 1789 that disposes that "People are born and remain free and equal in rights" 3 .

\section{Social Justice}

Social justice is one of the most important factors in the legitimacy of the social, economic, political order, and is closely related to the general inequality phenomenon created by the uneven distribution among important individuals and social group resources. Social justice is a legal, political and contemporary key concept, usually considered as a value, a criterion of justice and a universal moral aspiration where ideals of social justice that actually show space, criteria and measures by which a society tends to consider legal or illicit a particular distribution. The theme of social justice is very important today, because the social order and keeping it also depends on who can enjoy legitimacy and cannot be based solely on the use of force. Social justice issues have gained a great importance due to the global economic crisis that has deepened and made dramatic the social inequalities, because "Wherever there is injustice, there is a threat to justice everywhere else in the world" 4 . The term "social justice" is used for the first time in Christian social ethics and is mentioned in points 410-414 in the Summary of the Catechism of the Catholic Church ${ }^{5}$, but his first great philosophical work devoted to this topic with the title "Mirage of Social Justice"6, comes from the economist Friedrich von Hayek in 1976, which denies the dimension of social excess of State and considers legitimate only a weak State.

Society practices social justice when it respects the dignity and rights of the person and when the role of the State and civil society is that of providing the conditions that allow the organizations and individuals to do what is their duty.

\section{Equality of Opportunities}

The principle of equal opportunities or chances, is the starting point and one of the cornerstones of the liberal State where are many people to compete with each other to achieve a single objective, which can only be achieved by one of the competitors. This principle is extended to a large extent due to the domination of a global conflict conception of society, for which the social life is considered to be a great race for achieving few results. Should be considered the fact that equality of starting points should be applied to all members of the social group without any distinction of religion, race, sex, class, etc.. Today, the State shall provide for the citizens equal opportunities, removing the obstacles that may hinder the development of an independent personality in cultural and professional terms and should guarantee everyone the same initial conditions, intervening if someone departs in social or cultural disadvantage. Equality of opportunities has support in all advanced countries, because there is undoubted merit to reconcile equality of justice with efficiency. Equality of opportunities even though seeks the reconciliation with the merit, has its weak point as it rests on the principle "wins the best" by penalizing the "weak". The principle of equality must be enforced by the authority of political power and guaranteed by the Constitution of Kosovo, which in Article 7, par. 1 states that "the Constitutional Order of the Republic of Kosovo is based on the principles of freedom, peace, democracy, equality, respect for human rights and fundamental freedoms and the rule of law, non-discrimination, property rights, environmental protection, social justice, pluralism, separation of powers and the market economy", while in par. 2 continues that "Republic of Kosovo ensures gender equality as a fundamental value for the democratic development of society, equal opportunities for the participation of men and women $n$ in political, economic, social, cultural and other fields of social life".

\footnotetext{
3 "Men are born and remain free and equal in rights".

${ }^{4}$ Martin Luter King, Jr. "Letter from Birmingham Prison". April 1963.

${ }^{5}$ Summary of Catechism of the Catholic Church on June 28 2006.

${ }^{6}$ The mirage of social justice.
} 


\section{Equality in Justice}

Today whoever wins the election governs and who loses, stays in opposition controlling the actions of those who are called to make political choices, but without confusing the roles. In the Declaration of the Rights of Man and of the Citizen of 1789 , is talked about "human rights", the natural and inalienable rights and sacred, as witness the first article that opens with a consideration of freedom and equality "from birth" of all individuals. From the legal standpoint, the human rights attribute to every person a dignity that is independent from birth, nationality, personal and social conditions and are part of a "natural law" that exist and justify any form of "positive rights". With natural right is understood the set of rules that are not always codified and has its roots in the higher principles of justice and equality. For this reason, it is not surprising that many rights in modern constitutions are inspired by the Declaration of the Rights of Man and of the Citizen of 1789 , where Article 1 states that: "People are born and remain free and equal in rights. Social distinctions can be based only on common utilities". The principle of equality codified by the 1789 Declaration even though expressed in very general form is the starting point of the evolution of a concept, which has not finished yet. In several articles of this Declaration are present principles of equality that are very close to the principles of many the present constitutions, which in Article 6 the equality of citizens is guaranteed by law. Recognition of the principle of equality before the law is found in liberal constitutions in the nineteenth century, as in Article 24 of the Albertin Statute ${ }^{7}$, who states that: "All subjects of the Kingdom, whatever their title or rank is, are equal before the law. All equally enjoy civil and political rights, and are admitted to the civil and military offices, except in cases determined by law". According to Hobbes, about the justice may be seriously discussed only when is provided the condition a sovereign power, since justice as a property of relationships between human beings requires and presupposes that there is a government and is exercised a political power over a territory. According to John Rawls, the social justice demands include a strong component of equality among citizens, as expressed by the principles that simplify the politic interpretation of democratic equality, and that makes sense and applies only within the confines of a society, which corresponds to a state -nation. Also John Rawls states that "Justice is a set of rules governing the distribution of" goods "in the broad sense that allows or encourages cooperation among social actors with equal dignity. It absorbs equality that must be met by individual freedom, taken as a necessity and a limitation"s. Should consider and the potential tension between equality and other values worthy of protection as: between the equality and freedom, between equality and property rights, or between protection of the equality and respecting differences. This fact brings that equality, the difference and ownership of goods, are all worthy to be promoted and protected by law. It is worth noting that at a time when the state proclaims a principle of formal equality and provides tools for substantive equality, is put in the will of citizens the achieving of political, economic, social and cultural rights at the highest level.

\section{Special Exceptions to Equality}

It may happen that objective circumstances impede an equality of treatment, as the Constitution itself makes some exceptions to this principle. These exceptions are contained in the Constitution of Kosovo which excludes members from civil, criminal and administrative liability, "for opinions expressed and votes cast during exercise of their functions" (Article 75, par. 1). And "can be arrested only by special procedures" (Article 75, par. 2). In the same way and the "Government members enjoy their immunity because of their activity" (Article 98). Even the President of the Republic, being the only one in his position, it is understandable to be treated differently in the areas of criminal law, as prescribed by Article 89 of the Constitution of Kosovo, which disposes that "The President of the Republic of Kosovo enjoys immunity from prosecution, civil lawsuit and dismissal for actions and decisions within the scope of responsibilities of the President of the Republic of Kosovo" (Article 89). But the President of the Republic should be liable only in cases of committing serious crimes or when he seriously has violated the Constitution as provided in Article 91, par. 1 of the Constitution of Kosovo when states that: "The President of the Republic of Kosovo can be dismissed from the Assembly if he / she is convicted of a serious crime or if she / he is not / able to exercise the responsibilities of office due to serious illness or if the Constitutional Court has determined that he / she has committed a serious violation of the Constitution".

\footnotetext{
${ }^{7}$ Albertin status has this name from king Carlo from Savona and it was the constitution approved by the Kingdom of Sardinia and Piemonto in Torino on March $4^{\text {th }} 1848$.

${ }^{8}$ John Rawls, "The Justice Theory" Cambridge 1971,f 35(J. Rawls, A theory of Justice, The Belknap Press of Harvard University Press, Cambridge , Mass, 1971 ( The theory of Justice, Milano, Feltrinelli, 1997, p. 35). 


\section{Equality Before the Law}

Equality of all before the law is along with the freedom, a fundamental human right and one of the basic rules of a democratic society. In Kosovo, equality under the law is guaranteed by Article 24 of the Constitution, which in par.1 is noted that "All are equal before the law. Everyone has the right of equal legal protection without discrimination". Democratic Constitutions also provide equality of citizens through free participation in political life and aim to provide equal opportunities in social life, to give everyone the same opportunities for growth, personal and professional achievement. The only principle that proclaims the equality of all people and that it is universally accepted is the one that says "All men are equal before the law", or to put it another way "Law is equal for all". In the preamble of the French Constitution of 1791 it says that its drafters wanted to abolish "irrevocably the institutions which harm the freedoms and equality of all human rights" and among these institutions were parts all that have feudal character. While phrase which the preamble closes "There is no part of the nation, not to any individual more privileges or exceptions to the common law of all French people" illustrates better than any other comment, the meaning of the principle of equality before the law.

\section{Formal and Substantive Equality}

Equality can be formal or substantive.

Formal equality before the law means that all are equal before the law and that no one can put himself above the law and in turn putting a restriction to the legislator not to adopt discriminatory laws. The principle of formal equality applies to substantive equality and provides the commitment of the State and EU, not only to eliminate any privileged position that offends the equal dignity, but also to promote a policy of support and assistance to enable the full promotion of people and providing equal opportunities for all. Since for formal equality, all citizens have equal social dignity and are equal before the law, without discrimination of sex, race, language, religion, political opinions and personal conditions. Equality in civil and political rights is a formal equality, as concerns with the sphere of human rights and not to the goods and is compatible with a wider degree of social equality. The fact of being equal before the law and individual freedoms means that every individual should not be subject of discrimination.

While social equality, is substantial equality, since it does not have to do with the rights, but with the needs and connects to an equal distribution of goods. For the substantive equality, the State commits to remove inequalities, giving everyone the same opportunity of departure.

\section{Equality as Legal Rule and Constitutional Principle}

The need to respect the equality of men has constituted at any time a classic topic of legal reasoning, being used often in terms of enforcing the law regarding the constitutional or legislative announcements. In the context of modern constitutionalism equality is known more clearly in the field of law, by submitting a principle equipped with a general scope and are covered often especially by his normative constitutional strength. The opinion supported for some time by the Italian Supreme Court under which the constitutional guarantees of liberty and equality are addressed only to the legislator and for this reason cannot be applied by judges in any way, is opposed to a part of the doctrine ${ }^{9}$ and later the Constitutional Court ${ }^{10}$ under which norms qualified as programmatic may have the effect of determining anti constitutional of common laws affecting their constitutional interpretation.

\section{Legal Resources of Equality}

Rate which speaks very clearly about the equality principle is Article 3 of the Italian Constitution that emphasizes the formal and substantial profile.

Paragraph 1 of this article, noting that: "All citizens have equal social dignity and are equal before the law, without distinction of sex, race, language, religion, political opinion, social and personal conditions states the formal side of equality". But par. 1 would be meaningless if not followed by par. 2 which disposes that "It is the duty of the Republic to remove those obstacles of economic and social type that actually restrict the freedom and equality of citizens, that prevent the full development of human and effective participation of all workers in the political, economic and social organization of the country". This paragraph emphasizes the substantive side of that very important rate. It is worth to add

${ }^{9}$ Crisafulli, 1952; Pirandrei,1952; Napoli,1955.

10 Starting from the decision dated 14.06.2014, No.1. 
that Article 3 of the Italian Constitution is the article that is the judgment subject of the Italian Constitutional Court more than any other article. But his roots this principle has in the rights' declarations issued by modern revolutions, with illuminist inspiration and enlightenment of natural jurist, closely linking the equality, freedom and rights. In the Declaration of Independence of the American colonies in 1776 it is stated that "All men are created equal and are bearers of inalienable rights such as life, liberty and the pursuit of happiness". French Declaration of 1789, in Article 1 mentions that: "People are born and live free and equal in rights. Social distinctions may be based only on the common good". This principle would also be emphasized by the Universal Declaration of 1948 in which in Article 1 is noted that: "All human beings are born free and equal in dignity and rights". Prohibition of discrimination is later reaffirmed by the European Convention for the Protection of Human Rights and Fundamental Freedoms in 1950, giving more importance the effective protection of equality. It is enough to note the Article 14 of the Convention, which states that "the enjoyment of the rights and freedoms recognized from this Convention should be secured without discrimination; particularly those based on gender, race, color, language, religion, political opinions or to the others nature, national or social origin, membership of a national minority, property, birth or any other condition". Equality regarding freedom and rights has an important place in the current European order, which takes as its fundamental value and the principle for its realization. In the Treaty's Preamble of European Union, equality is mentioned among the "universal values" held by the European tradition. Equality appears in Title I among the values on which the European Union is founded, along with the respect for the human dignity, freedom, democracy, rule of law, respect for the human rights, including the rights of persons belonging to minorities, "as common values of the member States in a society characterized by pluralism, non-discrimination, tolerance, justice, solidarity and equality between women and men" (Articles 2, 3.3). Even the Card of Fundamental Rights, has devoted the entire Chapter III the formal equality, non-discrimination, respect for diversity, the rights of the most vulnerable, etc.. Article 20 of this Card states that "All persons are equal before the law", while article 21 states the ban of "Any form of discrimination, in particular, on race, gender, color or ethnic or social origin, genetic features, language, religion and political belief or any other opinion, membership of a national minority, property, birth, disability, age or sexual orientation and any discrimination based on nationality". Great importance has also the Directive 2000/43 of the Council of Europe, which relates to the treatment of persons despite of race or ethnic origin.

\section{Conclusion}

Today, a necessary condition to achieve full equality between men is the proper attention that should be given to different situations that may arise in reality, since inequalities in the delivering of the main goods like rights and liberties, income and wealth are justified when they go to benefit to the most disadvantaged. To the low cannot be required to "reconcile" the individuals, but not to treat unequally and not discriminate them, because the prohibition of discrimination is exactly the criteria specified by law to ensure full compliance with performance equality by examining differences arising from concrete situations. Protecting equality means not only eliminating inequalities but also protecting diversity, because even the Card of Fundamental Rights of the European Union includes respect for cultural, religious and linguistic diversity of individuals. Dworkin argues that "No government is legitimate if it is not concerned for the fate of all those citizens who claims to exercise sovereignty and which claims allegiance. If it is absent, then the government is only tyranny"11.

\section{References}

Alexis de Tocqueville, "Democracy and Poverty", Rome, 1998 (Democrazia e poverta. Ideazione, Roma, 1998).

Euripides, Supplici.

Jean-Jacques Rousseau, "The Social Contract”, University Library Rizzoli (BUR). ("Il contratto sociale", Biblioteca Universitaria Rizzoli

(BUR). Original French title "Du Contrat Social: ou principes du droit politique", 1762).

Summary of the Catechism of the Catholic Church, June 28, 2006.

Ronald Dworkin, "Sovereign Virtue. The theory of equality", Milan, Feltrinelli, 2002 (Ronald Dworkin. "Virtu sovrana. Teoria dell'uguaglianza", Milan, Feltrinelli, 2002).

Martin Luther King, Jr. "Letter from Birmingham Jail", April 1963.

Zygmund Bauman, "Social Europe Journal", 1988.

Italy's Constitutional Court, Decision No. 187, dated. 26.05.2010. (Corte Costituzionale italiana, N.187, del 26.05.2010).

${ }^{11}$ Ronald Dworking "Sovran virtue" Milano, Feltrineli,2000, page .7. (Ronald Dworking "Virtu sovrana", 2000,Milano, Feltrineli, 2002, p.7). 